\title{
The qualitative risk assessment model of riskote decision support system
}

\section{Nelson Mileu}

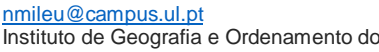
Território da Universidade de Lisboa, Portugal

\section{Margarida Queirós}

\section{margaridav@campus.ul.pt}

Instituto de Geografia e Ordenamento do Território da Universidade de Lisboa, Portugal

\begin{abstract}
Sendai Framework for Disaster Risk Reduction 2015-2030 identify among other principles that disaster risk reduction requires a multi-hazard approach and inclusive risk-informed decision-making. The development of a harmonized decision support tool to ensure that planning decisions are informed about the hazards affecting a given territory, the vulnerability of different land uses, exposed elements and options available to mitigate risks is crucial in the context of spatial planning. The objective of this paper is to describe the qualitative risk assessment model used in the development of the RiskOTe decision support system (DSS). RiskOTe is a spatial decision support system to assist spatial planning integrating the risk management component at municipal level. The qualitative risk assessment model used in RiskOTe is based on risk matrix that relates consequences and likelihood. Oeiras municipality was used as case study to demonstrate the applicability of the spatial decision support system. The scenarios obtained from the case study show that decision-making integrating risk analysis can be supported on a solid basis of information obtained from the system.
\end{abstract}

KEYWORDS:decision support system; risk assessment; spatial planning; land use transformation 


\section{INTRODUCTION}

Sendai Framework for Disaster Risk Reduction 2015-2030 identify among other principles that disaster risk reduction requires a multi-hazard approach and inclusive risk-informed decision-making based on the open exchange and dissemination of disaggregated data, including by sex, age and disability, as well as on the easily accessible, up-to-date, comprehensible, science-based, nonsensitive risk information, complemented by traditional knowledge (UN, 2015). Of significant importance to achieving the targets set out by Sendai Framework is the need for risk-informed decision-making based on Decision Support Systems (DSSs).Newman et al. (2017) states that the development and use of decision support systems for natural hazard risk reduction is increasingly important, mainly because natural hazards are having a significant impact on communities and economies; losses due to natural disasters are expected to increase into the future; risk reduction is broadly recognised as being more effective than response and recovery and risk reduction and residual risk affect communities and the natural environment in multiple ways, with complexity and uncertainty in causal processes driving hazard impacts. Different literature reviews of natural hazard risk-reduction decision support systems (NEWMAN et al., 2014; CIOCA and CIOCA, 2010; NEWMAN et al., 2017) show the importance of applying modelbased DSSs to decision problems. An important decision problem associated with disaster risk reduction is the promotion of disaster risk assessments into land-use policy development and implementation, including spatial planning. In Europe, Greiving et al. (2006) revealed that the role of spatial planning in risk assessment and management show many ways and has been overestimated. These differences were also studied by Peltier(2005), comparing the risk maps contents, the type of zoning and the associated restrictions in spatial planning between Switzerland (Valais), France (Hautes Pyrenees) and Italy (Aosta Valley), showing the existing differences and the importance of spatial planning and risk maps in disaster risk reduction.

Despite the double importance of integrating spatial planning in risk assessment and management and applying model-based DSSs to spatial planning decision problems, there are few examples, for this type of developments and implementations (MILEU, 2016).

Considering the importance of integrating spatial planning in riskassessment and management and applying model-based DSSs to spatial planning decision problems, a tool was developed (hereinafter termed RiskOTe DSS) to assist spatial planning integrating the risk management component at municipal level. Different approaches in risk assessment can be carried out with a range of methods. This paper presents the qualitative risk assessment model established in the implementation of RiskOTe DSS based. In addition, Oeiras municipality was used as case study to demonstrate the applicability of the decision support system in spatial planning.

The remainder of this paper is organized as follows: the modelling framework, the risk assessment approach, the arquitecture and interface of RiskOTe DSSisdescribed in Section 2. The case study description, the data used and the developed scenarios are given in Section 3. Finally, a summary of the findings and an outline of future research directions are provided in Section 4. 


\section{MATERIALS AND METHODS}

\section{Modelling framework}

A review of risk literature show different risk definitions (EMRICH, 2005). Considering the RiskOTe SDSS development and implementation, a risk definition was adopted, to support decision making. The risk definition used in this article is the "the combination of the probability of an event and its negative consequences" (UNISDR., 2009: p. 25).

$$
\mathrm{R}=\text { Probability } \times \text { Consequences, }
$$

In the SDSS analysis process (Figure 1) the following phases can be identified: 1) Definitions; 2) Analysis components; 3) Generation and analysis of results; 4) Decision making. The first phase corresponds to the definition of the geographic area in which the scenarios of risk analysis will be applied, risk selection and initial settings. The second phase consists on the definition of the components for the risk analysis model. In this paper only the qualitative analysis model will be explored. The following phase uses the multicriteria SMG model (Saunders, 2012: 168), to obtain the severity of consequences across all consequences. After the consequences have been determined, the likelihood is evaluated. Once the consequences and probability have been determined, the risk-based land-use planning can be assessed. 


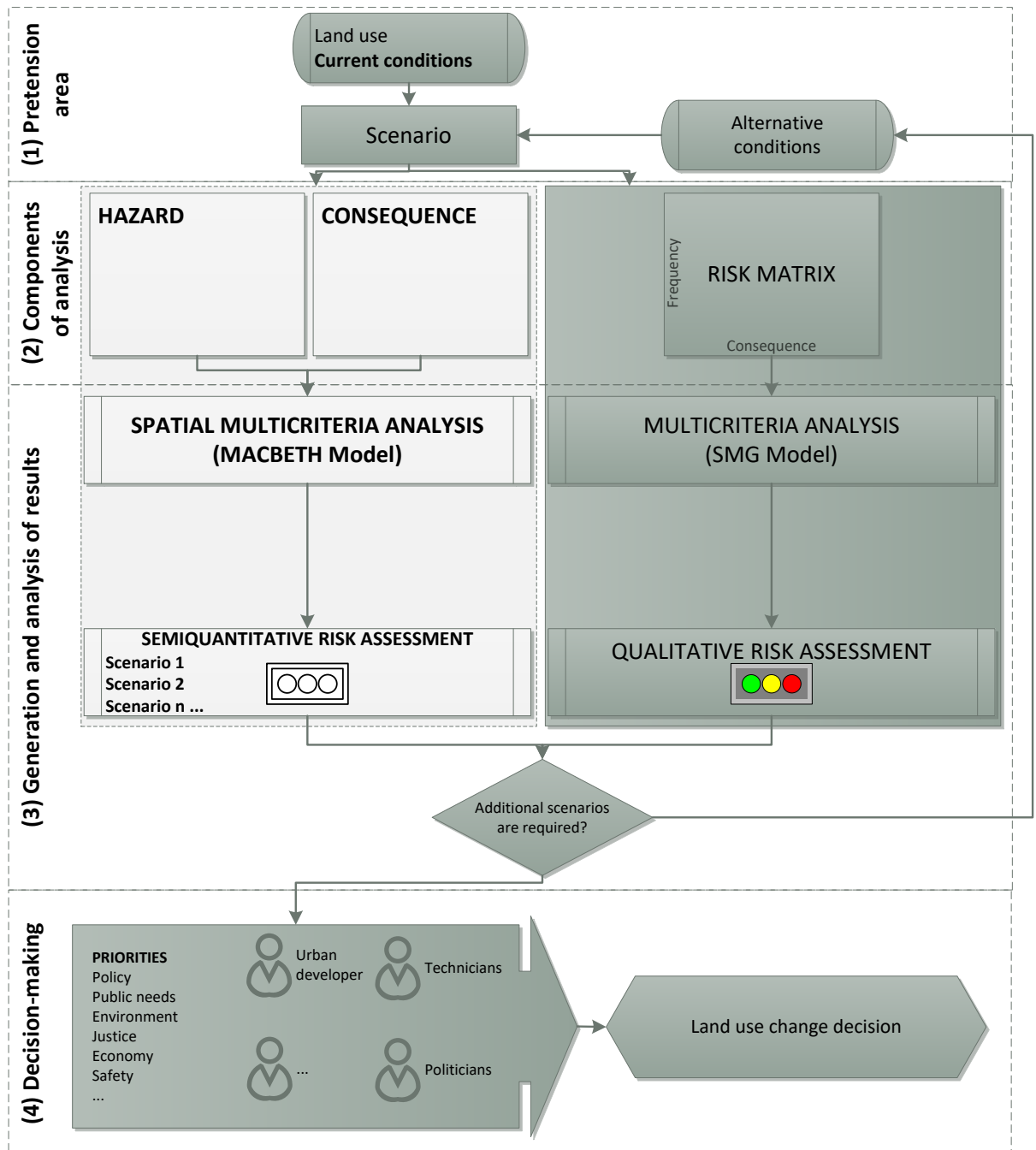

Figure 1.RiskOTe SDSS analysis process.

The last phase is about decision-making. The decision-making process is treated in RiskOTe as the possibility to save and compare different scenarios. The governance issues related with processes, priorities or actions by which stakeholder guides himself when decisions about spatial planning in risk-prone areas area taken and implemented are not part of RiskOTe. The Riskote system does not intend to obtain the decision but to provide support to the political decision-making process.

\section{Qualitattive risk approach}

The qualitative risk assessment model used in RiskOTe is based on a risk matrix that relates consequences and likelihood, adapted from Saunders (2012). The consequences matrix (Table 1)includes four type of metrics: Health and Safety; Social; Economic and Environment. For each type of metric, different impact measures allow to classify the disaster. The final overall level of impact is determined by SMG model ( $\mathrm{S}=$ seriouness, $\mathrm{M}=$ manageability and $\mathrm{G}=$ growth) where the following weights were adopted: Victims: 50\%, Buildings: $25 \%$, Economy: 15\% and Environment: 10\% 
Table 1.Consequence matrix.

\begin{tabular}{|c|c|c|c|c|c|}
\hline Severity of impact & Health \& Safety & Social & Economic & Environment & $\begin{array}{l}\text { Severity of } \\
\text { consequence }\end{array}$ \\
\hline 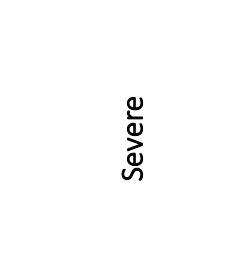 & $\begin{array}{l}\text { Multiple fatalities, } \\
\text { or significant } \\
\text { irreversible effects } \\
\text { to }>50 \text { persons. }\end{array}$ & $\begin{array}{l}\text { On-going serious } \\
\text { social issues. } \\
\text { Significant } \\
\text { damage to } \\
\text { structures and } \\
\text { items of cultural } \\
\text { significance. }\end{array}$ & $\begin{array}{l}\text { Severe i.e. over } \\
\$ 10 \text { million -or- } \\
\text { more than } 50 \% \\
\text { of assets. }\end{array}$ & $\begin{array}{l}\text { Severe, long-term } \\
\text { environmental } \\
\text { impairment of } \\
\text { ecosystem } \\
\text { functions }\end{array}$ & 6 \\
\hline$\frac{\overline{0}}{\frac{\pi}{\pi}}$ & $\begin{array}{l}\text { Single fatalities } \\
\text { and / or severe } \\
\text { permanent } \\
\text { disability }(>30 \%) \\
\text { to one or more } \\
\text { people. }\end{array}$ & $\begin{array}{l}\text { On-going serious } \\
\text { social issues. } \\
\text { Significant } \\
\text { damage to } \\
\text { structures and } \\
\text { items of cultural } \\
\text { significance. }\end{array}$ & $\begin{array}{l}\text { Major i.e. } \\
\text { between } \$ 1 \\
\text { million and } \$ 10 \\
\text { million -or- } 10- \\
50 \% \text { of assets. }\end{array}$ & $\begin{array}{c}\text { Very serious, long- } \\
\text { term } \\
\text { environmental } \\
\text { impairment of } \\
\text { ecosystem } \\
\text { functions }\end{array}$ & 5 \\
\hline 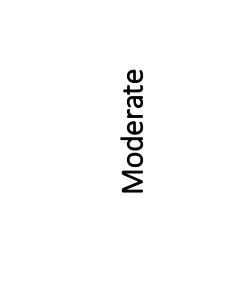 & $\begin{array}{l}\text { Moderate } \\
\text { irreversible } \\
\text { disability or } \\
\text { impairment } \\
(<30 \%) \text { to one or } \\
\text { more persons. }\end{array}$ & $\begin{array}{l}\text { On-going serious } \\
\text { social issues. } \\
\text { Significant } \\
\text { damage to } \\
\text { buildings and } \\
\text { items of cultural } \\
\text { significance. }\end{array}$ & $\begin{array}{c}\text { Moderate i.e. } \\
\text { between } \\
\$ 100,000 \text { and } \$ 1 \\
\text { million -or- } 10 \% \\
\text { of assets. }\end{array}$ & $\begin{array}{l}\text { Moderate, short- } \\
\text { term effects by } \\
\text { not affecting } \\
\text { ecosystem } \\
\text { functions }\end{array}$ & 4 \\
\hline$\stackrel{\grave{o}}{\stackrel{\grave{c}}{\Sigma}}$ & $\begin{array}{c}\text { Reversible injury } \\
\text { possibly requiring } \\
\text { hospitalization. }\end{array}$ & $\begin{array}{l}\text { social issues. } \\
\text { Significant } \\
\text { damage to } \\
\text { buildings and } \\
\text { items of cultural } \\
\text { significance. }\end{array}$ & $\begin{array}{l}\text { Minor i.e. } \\
\text { between } \$ 10,000 \\
\text { and } \$ 100,000- \\
\text { or- } 1 \% \text { of assets. }\end{array}$ & $\begin{array}{l}\text { Minor effects on } \\
\text { physical } \\
\text { environment }\end{array}$ & 3 \\
\hline & & $\begin{array}{l}\text { Medium-term } \\
\text { social issues, } \\
\text { minor damage } \\
\text { to dwellings.. }\end{array}$ & $\begin{array}{c}\text { Minor i.e. } \\
\text { between } \$ 10,000 \\
\text { and } \$ 100,000- \\
\text { or- } 0.1 \% \text { of assets }\end{array}$ & & 2 \\
\hline$\frac{\frac{0}{0}}{\frac{.00}{-00}}$ & $\begin{array}{l}\text { Minor first aid or } \\
\text { no medical } \\
\text { treatment } \\
\text { required. }\end{array}$ & $\begin{array}{l}\text { Negligible short- } \\
\text { term social } \\
\text { impacts on local } \\
\text { population, } \\
\text { mostly } \\
\text { repairable. }\end{array}$ & $\begin{array}{l}\text { Small i.e. less } \\
\text { than } \$ 10,000- \\
\text { or- } 00.1 \% \text { of } \\
\text { assets }\end{array}$ & $\begin{array}{l}\text { Insignificant } \\
\text { effects on physical } \\
\text { environment }\end{array}$ & 1 \\
\hline
\end{tabular}

Adapted from Saunders (2012: 166)

The determination of likelihood for each hazard follow a likelihood scale(Table 2) with seven levels. 
Table 2.Likelihood scale.

\begin{tabular}{|c|c|c|c|}
\hline Level & Descriptor & Description & Indicative frequency \\
\hline 7 & Almost certain & $\begin{array}{c}\text { The event will occur on an annual } \\
\text { basis }\end{array}$ & Once a year or more frequently \\
\hline 6 & Likely & $\begin{array}{c}\text { The event has occurred several } \\
\text { times in your lifetime }\end{array}$ & Once every three years \\
\hline 5 & Possible & $\begin{array}{c}\text { The event might occur once in } \\
\text { your lifetime }\end{array}$ & Up to once every ten years \\
\hline 4 & Unlikely & $\begin{array}{l}\text { The event does occur somewhere } \\
\text { from time to time }\end{array}$ & Once every 30 years \\
\hline 3 & Rare & $\begin{array}{c}\text { Possible but not expected to occur } \\
\text { except in exceptional } \\
\text { circumstances }\end{array}$ & Once every 100 years \\
\hline 2 & Very rare & $\begin{array}{c}\text { Possible but not expected to occur } \\
\text { except in exceptional } \\
\text { circumstances }\end{array}$ & One in 1000 years \\
\hline 1 & Almost incredible & $\begin{array}{l}\text { Theoretically possible but not } \\
\text { expected to occur }\end{array}$ & One in 10,000 years \\
\hline
\end{tabular}

Adapted from Saunders (2012: 170)

Using the outcomes from consequences (severity of impact score) and likelihood matrix (likelihood level) the level of risk is determined as a function of consequences multiplied by likelihood. The matrix is classified in fourcolors that can be used as descriptors for land use control (Table 3).

Table 3.Risk matrix.

\begin{tabular}{|c|c|c|c|c|c|c|}
\hline $\begin{array}{l}\text { Consequences } \\
\text { Likelihood }\end{array}$ & $\mathbf{1}$ & $\mathbf{2}$ & $\mathbf{3}$ & $\mathbf{4}$ & $\mathbf{5}$ & $\mathbf{6}$ \\
\hline $\mathbf{7}$ & 7 & 14 & 21 & 28 & 35 & 42 \\
\hline $\mathbf{6}$ & 6 & 12 & 18 & 24 & 30 & 36 \\
\hline $\mathbf{5}$ & 5 & 10 & 15 & 20 & 25 & 30 \\
\hline $\mathbf{4}$ & 4 & 8 & 12 & 16 & 20 & 24 \\
\hline $\mathbf{3}$ & 3 & 6 & 9 & 12 & 15 & 18 \\
\hline $\mathbf{2}$ & 2 & 4 & 6 & 8 & 10 & 12 \\
\hline $\mathbf{1}$ & 1 & 2 & 3 & 4 & 5 & 6 \\
\hline
\end{tabular}

Adapted from Saunders (2012)

The land use control levels increase with the level of risk, supporting possible decision-making (Table 4). 
Table 4.Qualitative levels of risk based.

\begin{tabular}{|l|l|}
\hline \multicolumn{1}{|c|}{ Level of risk } & \multicolumn{1}{c|}{ Level of land use control } \\
\hline Acceptable & Permitted \\
\hline Tolerable & Controlled \\
\hline $\begin{array}{l}\text { Tolerable with } \\
\text { consent }\end{array}$ & $\begin{array}{l}\text { Discretionary, restricted } \\
\text { Discretionary }\end{array}$ \\
\hline Intolerable & No complying, prohibited \\
\hline
\end{tabular}

Adapted from Saunders (2012)

\section{RiskOTe Architecture}

RiskOTe SDSS is a client-server application. The RiskOTetechnical architecture is organized into three tiers (Figure 2). The "data layer" is responsible for storing and managing the data and is supported on the PostgreSQL DBMS withthe PostGIS extension for spatial data storage and analysis.

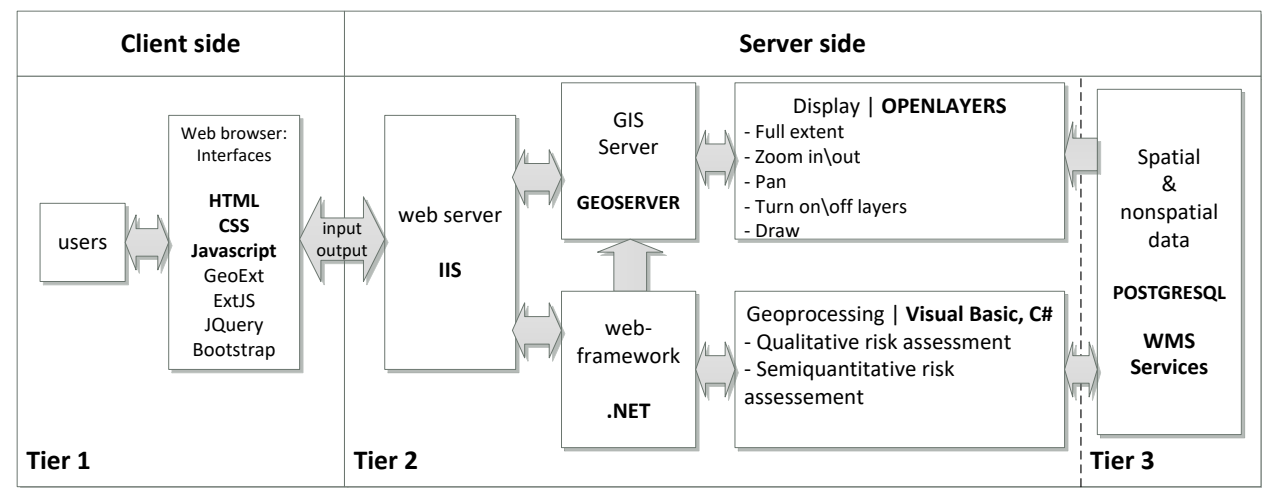

Figure 2.RiskOTearquitecture.

The "application layer" corresponds to the core of the application and is responsible for controlling its functionalities, as well as having the ability to perform the data transition between the presentation and data layers. This layer integrates the GeoServer map server. GeoServer is used to publish the spatial data stored in the database as Web Map Service (WMS), namely the affected area polygon from different scenarios. The application development was performed using Visual Studio 2013. For the development, the Visual Basic .NET programming language was used as support for the development of all functionalities. The "client layer" or presentation layer is the highest-level layer and is responsible for the user/application contact through a set of interfaces that are presented in the browser. This layer was developed in HTML5 and JavaScript, via the use of a set of support libraries such as the OpenLayers JavaScript library for displaying geographic data in browsers, the GeoExt JavaScript library for building web applications with modern interfaces, and other libraries such as Bootstrap and jQuery. 


\section{Design of the tool}

In the set-up of the tool, four steps were considered. These steps are the following: (1) RiskOTE SDSS home page; (2) Multicriteria weighting; (3) Scenario definitions; 4) Results and comparison of scenarios.

The first page of the RiskOTe SDSS should be considered as the "knowledge base" and as a gateway to its use (Figure 3a). In the next step, the user should evaluate the weights for the victims, buildings, economy and environment components. The default weights weredefined from SMG model (Figure 3b). These values can be redefined by the user, depending on the purpose of each scenario. The third step of the RiskOTe decision support system corresponds to definition of the scenario: scenario name, probability and consequence level selection for each hazard(Figure 3c). Regarding the establishment of a link between the affected area and the risk assessment a polygon could be drawn by the user to identify the impact area. In the last step the risk assessment is shown and different scenarios results can be compared(Figure 3d).

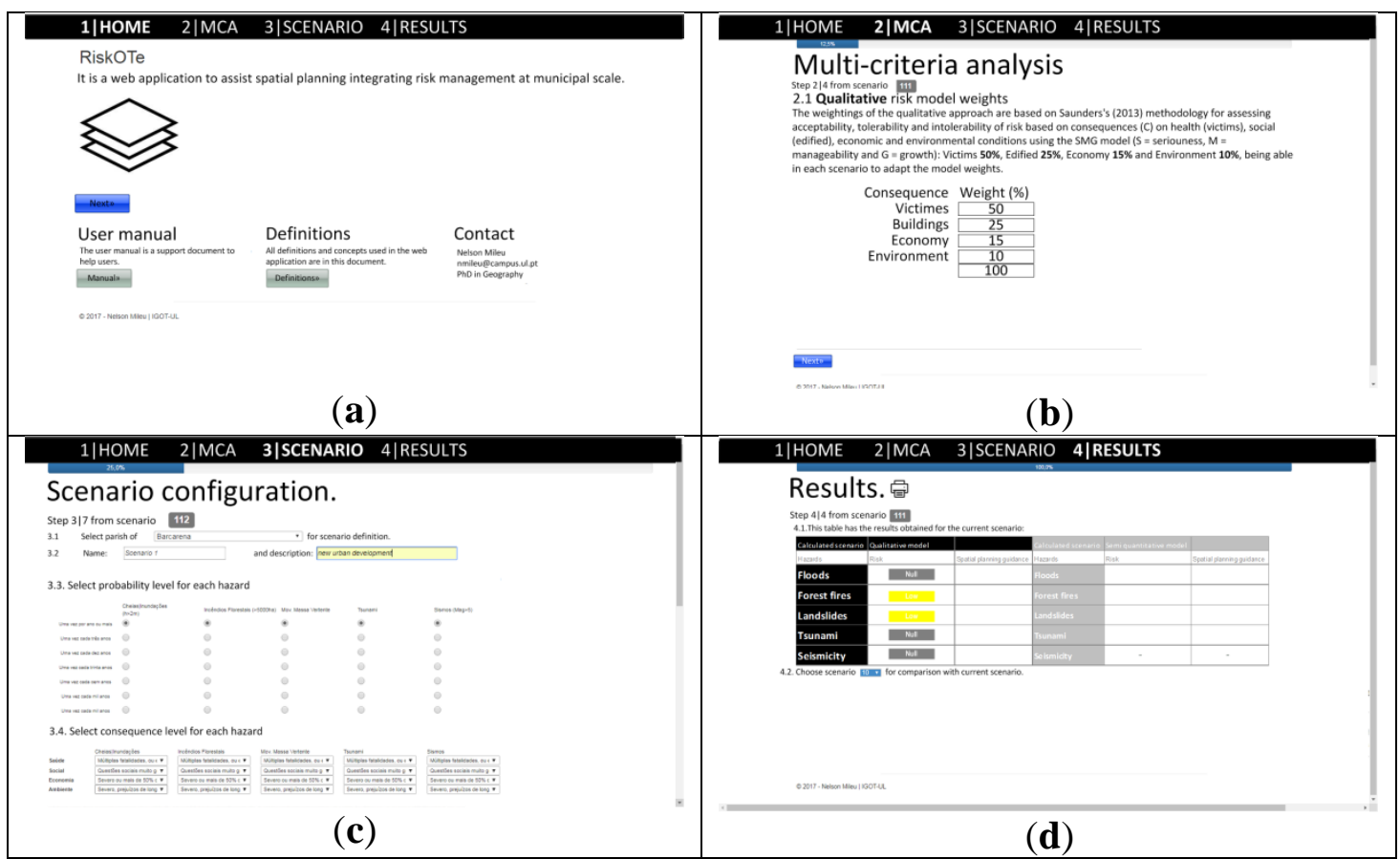

Figure 3.RiskOTe interface: (a) Home page; (b) Multi-criteria weights definition; (c) Scenario configuration; (d) Results.

\section{CASE STUDY}

\section{Study Area}

The municipality of Oeiras is the case study that is used to test the applicability of the methodology at municipal level and the implementation of the RiskOTe decision support system. The municipality of Oeiras is located in the Lisbon Metropolitan Area, Portugal (Figure 4). It is a predominantly urban 
municipality with a population of 172,120 inhabitants and a high economic development associated with medium-sized and large-sized business locations, mainly associated to higher tertiary activities (MUNICÍPIA, 2013).

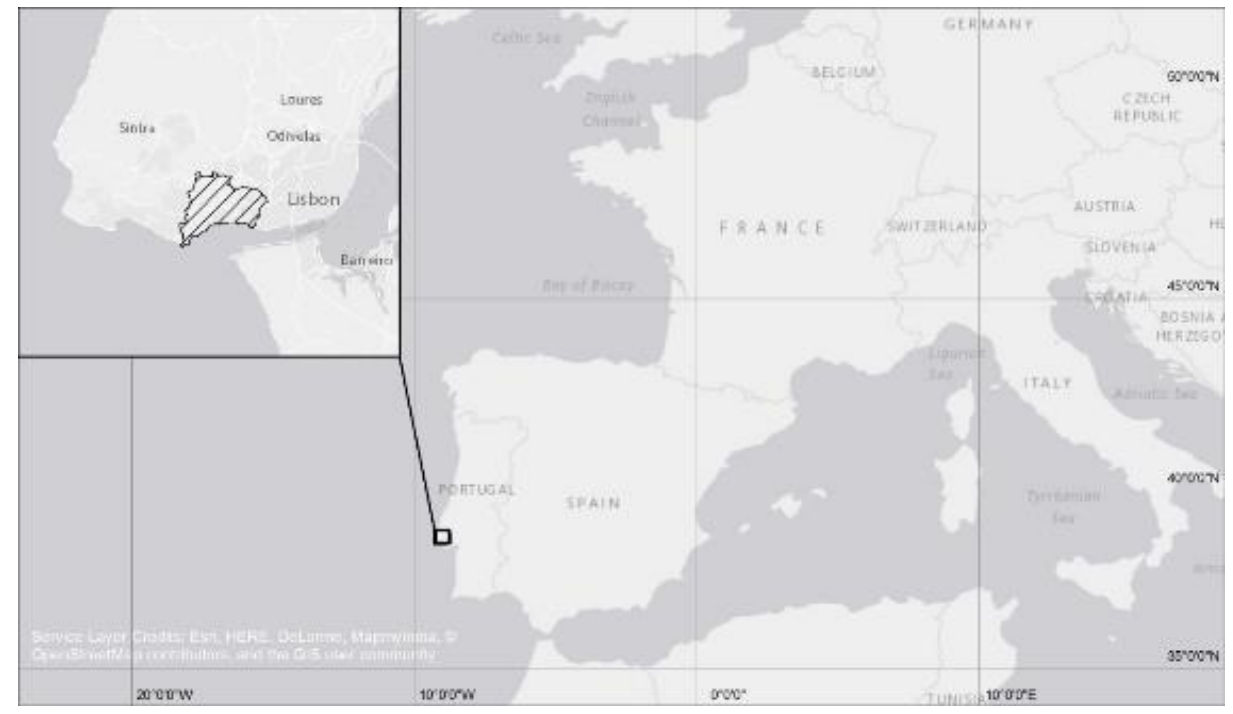

Figure 4.Case study location.

The consequences and likelihood metrics were obtained from municipal events database and from the reports of the storm events occurred in 1996 and 1997.

\section{Scenarios}

The scenarios implemented in RiskOTe DSS are intended to provide a global view on spatial planning guidelines, considering a qualitative risk analysis. For testing RiskOTe SDSS, two scenarios were developed.

\section{Scenario 1}

For the first scenario, the consequences were based on the storm event of January 8, 1996. According to the report "Bad weather in revision" (CMO, 1996) elaborated by the Municipality of Oeiras, an amount of losses of approximately 2.562.345 Euroswas estimated and the following damages were identified:

Several municipal roads and streets affected, including sidewalks;

Several public transport shelters destroyed or damaged;

Damaged public gardens and tree falls;

Municipal Swimming Pool affected by the violent storm;

Stream channel destroyed;

Rainwater and domestic sewer networks affected in several locations;

Destruction of slum of 18 families in different places, 13 in Alto da Loba (Paço de Arcos), which forced the immediate temporary accommodation of 42 people; 
Significant damages in dwellings of more than 20 people;

Damages ( associated with floods and landslides) in private dwellings;

Significant damage to municipal dwellingsrelated with flooding and damagesin the roofs.

The first exploratory scenario uses the default weights defined by the system. The impact area is in the parish of Oeiras and corresponds to the yellow polygon (Figure 5).

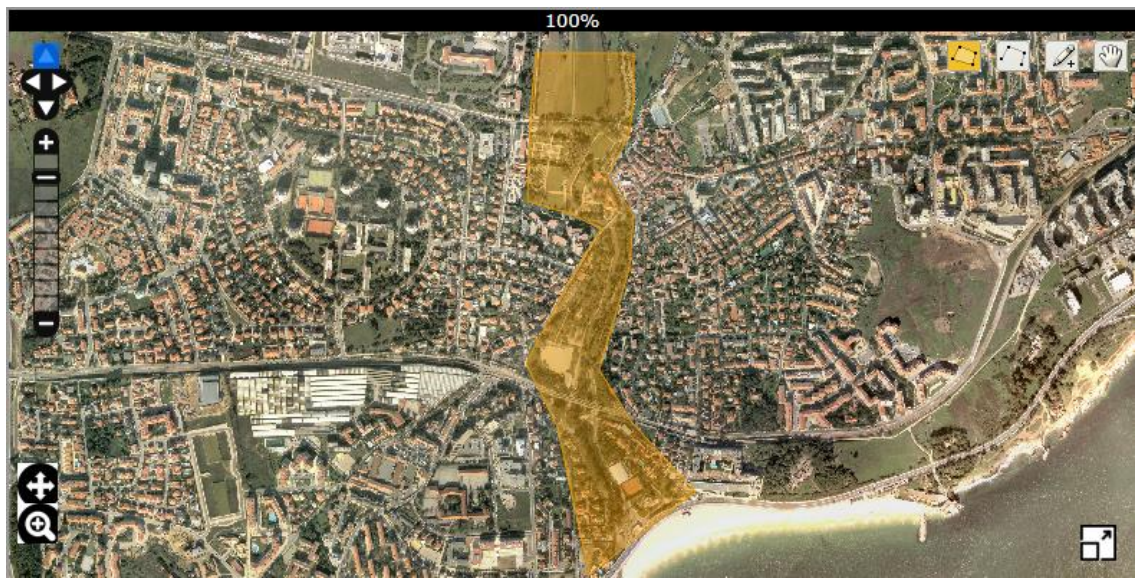

Figure 5.Scenario 1 impact area.

Regarding the probability and consequences associated with the qualitative assessment (Figure 6), they were only defined for floods and were based on the context described previously for the storm of January 8, 1996.

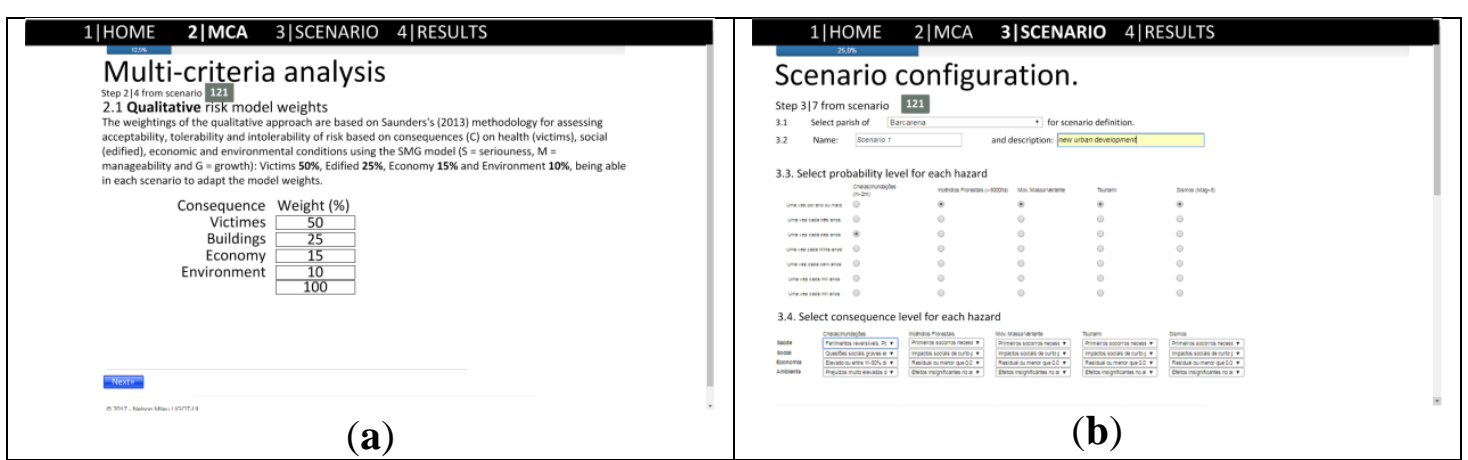

Figure 6.Scenario 1 multi-criteria weights and configuration: (a) Multi-criteria weights definition; (b) Scenario likelihood and consequences configuration.

The qualitative risk assessment result for this scenario (Figure 7), show a "Tolerable with consent" risk, and an indication for land-use planning where landuse transformation should be subject to restrictions. 


\section{1|HOME $\quad 2 \mid$ MCA $\quad 3 \mid$ SCENARIO 4|RESULTS}

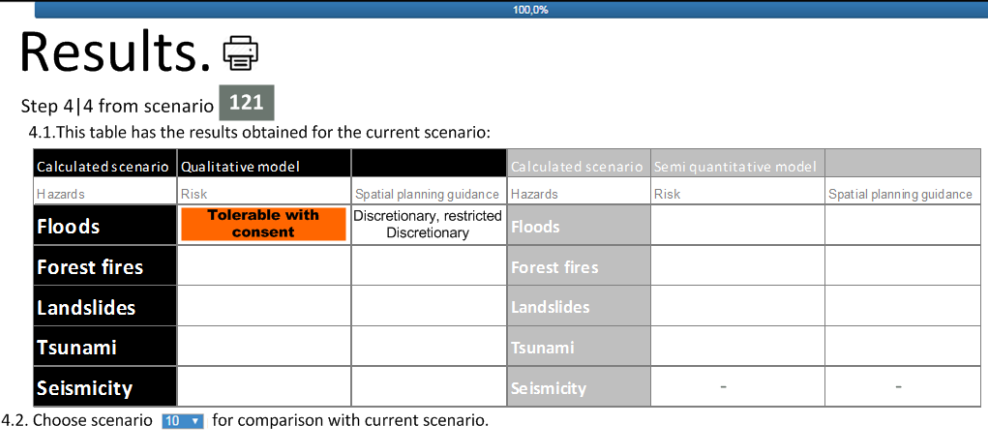

Figure 7.Scenario 1 results.

\section{Scenario 2}

The adverse weather situation corresponding to a storm occurred on November 2, 1997, was used as reference to obtain the consequences for the second scenario. According to the report "Storm: November 1997" (CMO, 1997) elaborated by the Municipality of Oeiras, the direct losses were estimated approximately in 3.988.275 Euros. With particular incidence in the places of Algés and Cruz Quebrada / Dafundo, it was also possible to identify the following damages:

Rainwater and domestic sewage networks destruction;

Drainage systems affected;

Roads destruction;

Landslides affecting support walls;

Flooding and sludge in streets and buildings;

Total destruction of 36 dwellings;

Floods and / or destruction of assets in 116 basements of privately owned buildings;

More than 100 commercial establishments with losses in the building, equipment or materials / merchandise, with particular incidence in the downtown of Algés.

This exploratory scenario uses the default weights defined by the system. The impact area is in the parish of Algés and corresponds to the yellow polygon (Figure 8). 


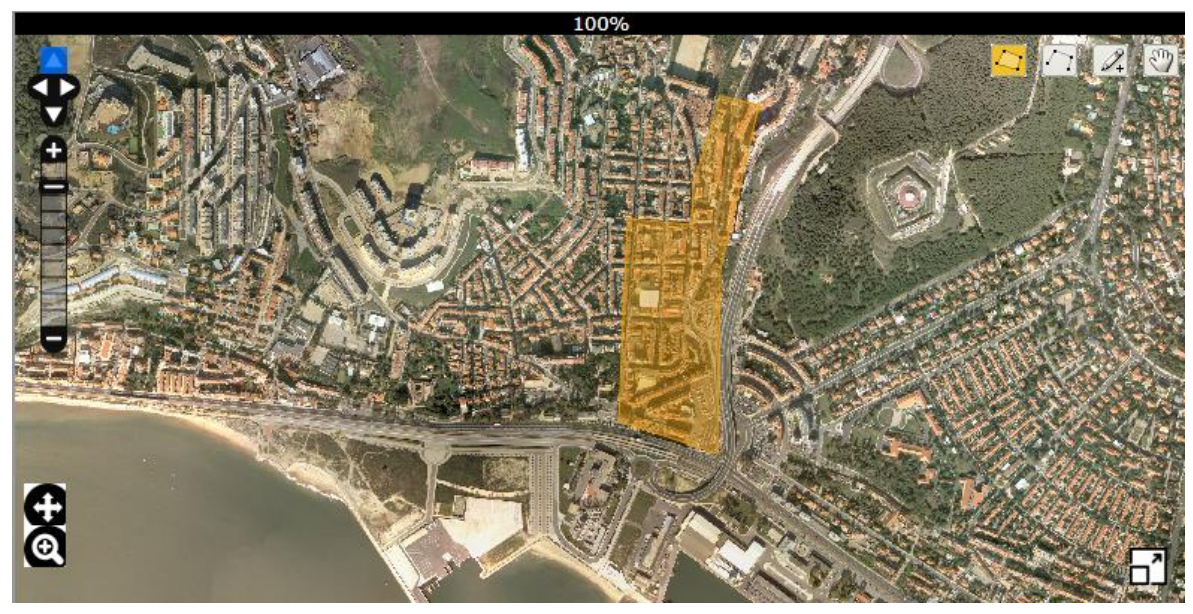

Figure 8.Scenario 2 impact area.

Regarding the probability and consequences associated with the qualitative assessment (Figure 9), they were only defined for floods and were based on the context described previously for the storm of November 2, 1997.

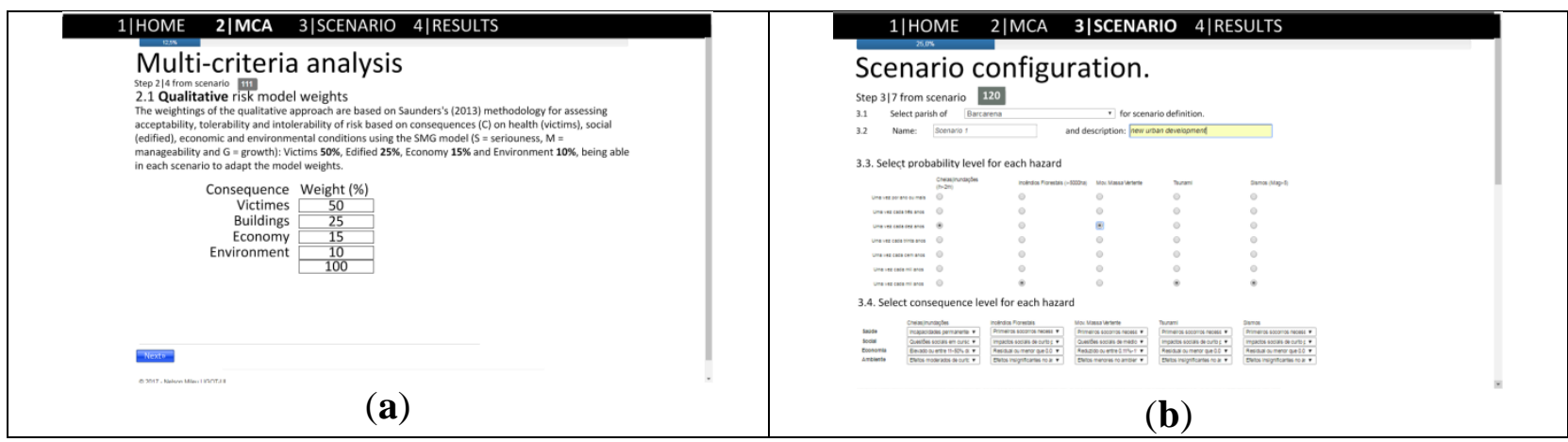

Figure 9. Scenario 2 multi-criteria weights and configuration: (a) Multi-criteria weights definition; (b) Scenario likelihood and consequences configuration.

For this scenario, the qualitative risk assessment resulted in a "Tolerable with consent" risk, and an indication for land-use planning where land-use transformation should be subject to restrictions (Figure 10). 


\section{1|HOME 2|MCA 3|SCENARIO 4|RESULTS}

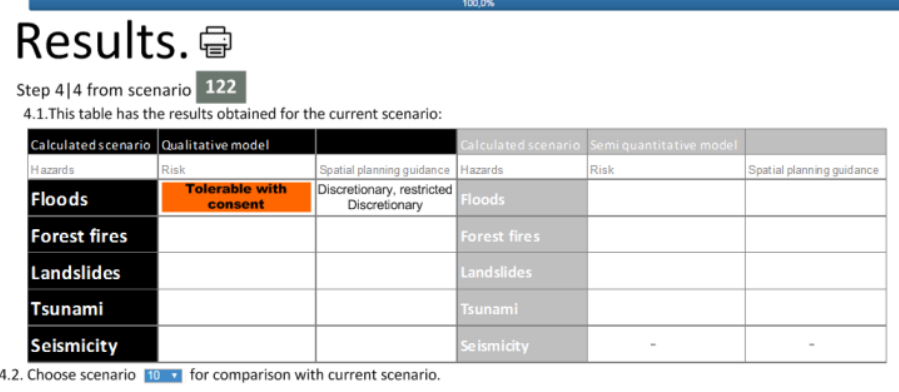

Figure 10.Scenario 2 results.

\section{CONCLUSIONS AND DISCUSSION}

Considering the first priority for action of Sendai Framework for Disaster Risk Reduction about "Understanding disaster risk", the policies and practices for disaster risk management should be based on an understanding of disaster risk in all its dimensions. Such knowledge can be leveraged for the purpose of predisaster risk assessment, for prevention and mitigation and for the development and implementation of appropriate preparedness and effective response to disasters. RiskOTe DSS implementation made possible to conceptually define a decision support system to help decision makers at local scale to determine levels of risk and contribute to achieve the targets set out by Sendai Framework. This contribution is related with the promotion of real time access to reliable data, make use of space and in situ information, including geographic information systems (GIS), and use information and communications technology innovations to enhance measurement tools and the collection, analysis and dissemination of data.

With the implementation of RiskOTe it is possible to state that a decision support system has been conceptually defined based on a qualitative risk assessment model allowing the elaboration of scenarios that can support the decision on the transformation of land use. The scenarios in this article reinforce the framework described by Saunders and Kilvington (2016) showing that is possible to develop risk-based land use planning, supporting the inclusion of natural hazard risk assessments in land use decisions. The inclusion of natural hazard risk assessments in land use decisionsbased onRiskOTe, allowmunicipalities to be aware of and explore vulnerability challenges when making policy and planning decisions.

However, the implementation in RiskOTe of the qualitative risk assessment model found some issues. The first problem found in the scenarios development was to obtain systematic data on catastrophic consequences. Although it was possible to obtain two detailed reports for the case study, the reality shows that it 
is not always possible to obtain detailed data on the consequences of catastrophes. Another problem is the link establishment between the geographic area of impact and the consequences. The geographic limit of affected areas is not always a reality. The last problem is the risk assessment framework and the interface. When the user is selecting the levels of probability and consequences some difficulties have arisen due to the large number of options.

The future directions of the research point to the possibility of generating additional scenarios for urban development projects that incorporate mitigation measures (e.g. retention basins) with consequences on probability or consequences levels as well as the possibility of developing risk scenarios associated with climate change. 


\section{REFERÊNCIAS}

Cioca, M. \&Cioca, L. (2010). Decision Support Systems used in Disaster Management, Decision Support Systems, Chiang S. Jao (Ed.), ISBN: 978-953-761964-0, InTech. Available online: http://www.intechopen.com/books/decisionsupport-systems/decision-support-systems-used-in-disastermanagement. (accessed on 2 May 2018)

CMO - Câmara Municipal de Oeiras (1996). Intempéries em Revisão. Plano de Actividades. Relatório da Situação, Oeiras.

CMO - Câmara Municipal de Oeiras (1997). Intempéries - de 2 de novembro de 1997. Relatório, Oeiras.

Greiving, S.; Fleischhauer, M. \&Wanczura, S. (2006) - Management of Natural Hazards in Europe: The Role of Spatial Planning in Selected EU Member States, Journal of Environmental Planning and Management, Vol. 49, N. 5, pp. 739 757.

Mileu, N. (2016). Sistema de Apoio à Decisão na Gestão do Risco à Escala Municipal, PhDThesis, Universidade de Lisboa, Lisbon.

Municípia (2013). Oeiras, Factos e Números - Edição Especial, 1st ed., Município de Oeiras, Oeiras.

Newman, J.; Maier, H.; Riddell, G.; Zecchin, A.; Daniell, J.; Schaefer, A,; van Delden, H.; Khazai, B.; O'Flaherty, M. \& Newland, C. (2017). Review of literature on decision support systems for natural hazard risk reduction: Current status and future research directions, Environmental Modelling \& Software, 96, pp. 378-409.

Newman, J; Maier, H.; Delden, H.; Zecchin, A.; Dandy, G.; Riddel, G. \& Newland, C. (2014). Literature Review on Decision Support Systems for Optimising Long-Term Natural Hazard Mitigation Policy and Project Portfolios, Report n.o 2014.009, Bushfire and Natural Hazards CRC, Melbourne.

Peltier, A. (2005). La Gestion des Risques Naturels dans les Montagnes d'europe Occidentale - Etude comparative du Valais (Suisse), de la Vallée d'Aoste (Italie) et des Hautes-Pyrénées (France), PhD Thesis, Université Toulouse II, Le Mirail. 
Saunders, W. \&Kilvington, M. (2016). Innovative land use planning for natural hazard risk reduction: A consequence-driven approach from New Zealand, International Journal of Disaster Risk Reduction, 18, pp. 244-255.

Saunders, W. (2012). Innovative land-use planning for natural hazard risk in New Zealand, PhD Thesis, University of Massey, Manawatu.

UN - United Nations (2015) - Sendai Framework for Disaster Risk Reduction 20152030.

Available

online: https://www.unisdr.org/files/43291_sendaiframeworkfordrren.pdf. (accessed on 2 May 2018)

UNISDR (2009).Terminology on Disaster Risk Reduction.United Nations International Strategy for Disaster Reduction, Geneva.

Recebido: 17 mai. 2018

Aprovado: 09 jul. 2018.

DOI: $10.3895 /$ rbpd.v7n4.8521

Como citar: MILEU, N.; QUEIRÓs, M. The qualitative risk assessment model of riskote decision support system. R. bras. Planej. Desenv.,Curitiba, v. 7, n. 4, p. 479-494, set./dez. 2018. Disponível em:

$<$ https://periodicos.utfpr.edu.br/rbpd>. Acesso em: XXX.

Correspondência:

Nelson Mileu

Alameda da Universidade 1649-004 Lisboa, Portugal

Direito autoral: Este artigo está licenciado sob os termos da Licença CreativeCommons-Atribuição 4.0

Internacional.

\section{(c) (1)}

